\title{
超小型衛星「鳳龍武号」の試験・検証と軌道上不具合原因究明*1 Test and Verification of Nanosatellite HORYU-II and Orbital Anomaly Investigation
}

\author{
趙 孟 佑*2・増 井 博 一²・九州工業大学衛星開発プロジェクト*2 \\ Mengu CHO, Hirokazu MASUI, Kyutech Satellite Project
}

Key Words: Nanosatellite, Verification, Reliability, Environment Test, Single Event

\begin{abstract}
HORYU-II is a $30 \mathrm{~cm}$-cubic shaped nanosatellite weighing $7 \mathrm{~kg}$ developed by Kyushu Institute of Technology. Its main mission is demonstration of high voltage technology. HORYU-II went through extensive tests utilizing the facilities of Center for Nanosatellite Testing at Kyushu Institute of Technology. We reflect on its verification and testing processes of the project that started in April 2010 and ended in May 2012. We consider the effectiveness of each process by comparing the results obtained after the launch that took place on May 18 , 2012. Especially, HORYU-II suffered serious anomaly for one month in June 2012 where it could not carry out any missions. We present the result of anomaly investigation.
\end{abstract}

\section{1. 目的および背景}

超小型衛星は, その低コスト・短納期という特徴から, 大 学・中小企業・途上国等による宇宙への新規参入の拡大や, 従来の中・大型衛星ではなし得なかった新たな宇宙利用の 開拓など，各界から大きな期待を寄せられている.

日本においても，2002 年に千葉工業大学による鯨生態観 測衛星, 2003 年に東京大学と東京工業大学によるキューブ サットが打ち上げられ, 超小型衛星が現実のものとなった. それ以来, 超小型衛星の開発は大学を中心として急速に広 まり, 2010 年 6 月迄に, 国内の大学または企業で開発され た 18 機の $50 \mathrm{~kg}$ 以下の超小型衛星が国内外のロケットによ り打ち上げられている。しかしながら, それらの衛星のミ ッション達成率は $50 \%$ に満たない. 超小型衛星の成功率の 低さは世界的に共通であり，文献 1)によれば，10kg 以下の 衛星でミッションを完全に達成したのは，48\%にとどまっ ている.また，衛星が打ち上げ後間もない時期に失われる 率も，衛星サイズが小さくなる程高くなる傾向にある ${ }^{2)}$. 超小型衛星の利用拡大をはかるためには, 信頼度向上が喫 緊の課題となっている.

超小型衛星は, 低コスト・短納期を達成するために, 従来 の中・大型衛星では行われない様々な設計を行う。宇宙用 ではない部品や技術を多用し, 最新の民生技術を未実証で あっても果敢に採用する。自主開発ではなく, インターネ ツト通販を含む市場調達によって搭載機器を調達すること も多々ある. 開発チームが小規模であるため, インターフ エースや設計全般をできるだけ簡単化し, 文書作業も最小 限のものにとどめている.

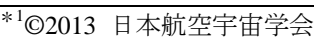

平成 24 年 11 月 20 日, 第 56 回宇宙科学技術連合講演会にて発表 平成 24 年 11 月 21 日原稿受付

*2 九州工業大学
}

しかしながら, サイズ, 電力, 通信速度といったリソー スの制限のために, 圥長性は限られており, 全体としての 信頼度が従来の衛星に比べて劣るのは否めない. また, 特 に大学衛星で学生が自主開発・製作する場合が多いために, 技術的に未熟な部分が完成品に含まれる危険がある. 更に は, プロジェクトマネージメントに不慣れな学生が多く, 衛星製作に手一杯で試験/検証に充分な時間を割けないま まに打ち上ってしまうことが少なくない.

更に, ピギーバック打ち上げを主とする超小型衛星の場 合，コールドロンチが義務づけられており，打ち上げ中の 不意の通電や展開を予防するために, スイッチを多段で直 列接続するなど, 多くの単一故障点になりかねない措置を ロケット側から要求される. また, 最近は, 衛星サイズに よらずに, 25 年内の軌道落下や運用後の Passivation が要求 されるようになっている.

このような制約がありながらも, 従来の思想に捉われな い自由な発想で開発を行い, 低コスト・短納期でありなが らも，ある程度の信頼度をもった衛星を開発しなければな らない, そのためには, 衛星の試験・検証において, 従来と は異なる考えが必要である。

本稿の目的は，2012 年 5 月 18 日に国内 19 機目の超小型 衛星として H2A ロケットにて打ち上げられた「鳳龍武号」 の試験・検証過程を振り返り, 軌道上結果と照合して, 試 験・検証の有効性を検討することである.また 2010 年 6 月 から 1 力月間にわたり, ミッションの実行が不可能になる という事態に陥ったが, その原因究明作業を通じて得られ た, 様々な知見についても述べる. 本稿は 5 章から構成さ れる. 2 章は, 鳳龍武号の設計・開発手法について述べる. 3 章で, 試験・検証の詳細と，その過程で見つかった不具合に ついて述べる. 4 章は, 軌道上の不具合とその原因究明作業 について述べる. 5 章では, まとめと今後の課題について 述べる. 


\section{2. 鳳龍式号の設計と開発}

「鳳龍式号」は九州工業大学の衛星開発プロジェクトに 参加する 20 から 30 名程の大学院生・学部生が開発を行っ た超小型衛星である. 軌道は高度約 $680 \mathrm{~km}$ の太陽同期軌道 である. 衛星は $30 \mathrm{~cm}$ 四方の立方体形状であり，重量は $7 \mathrm{~kg}$ である. 衛星の詳細は文献 3)等にある. 鳳龍弐号は世界初 の軌道上 $300 \mathrm{~V}$ 太陽光発電の達成等の技術実証を目的とし ているが, その目的よりも，学生がシステム工学を学習す るための教育衛星としての位置づけが優先する. そのため, 学生は衛星のミッション選択・概念設計から運用までの全 てに責任を持つことになっている. 鳳龍武号の開発・設計 においては, 以下の制約条件があった.

・プロジェクト開始が 2010 年 4 月であり, 打ち上げ予 定(当初は 2011 年秋を予定)まで 1 年半しかなく, H2A 副衛星選定(2010 年 9 月)からは, 僅か 1 年程で衛星を 納入しなければいけない.

・学生の技術レベルを超えない.

・宇宙用部品を購入する予算がない.

そのために以下を基本的な方針とした。

・2006 年から開発してきていたキューブサット「鳳龍」 のバスシステムを引き継ぐ.

・受動的な姿勢制御と展開物はアンテナに限定

・加工に関する熟練度が要求されるところ（基板への素 子のハンダ付け, 構造物の加工）は，外注する，学生は 設計図と部品を業者に渡す。

・バス用の太陽電池アレイは, 新規開発太陽電池アレイ の宇宙実証データとの提供の見返りとして, 宇宙メー カーに製作を依頼する.

・地上民生品・技術を使ってコストダウンを図るが，予 算の許す限りスケジュールを優先し, 例えば同じ基板 を 3 枚製作して, 試験を同時並行で行う.

設計の一例として構造設計について述べる. 衛星の内部 構造は, 第 1 図に示すように中心部に $3 \mathrm{U}$ のキューブサット を配置し，そのまわりをアルミ製の骨組みで $30 \mathrm{~cm}$ 四方に 拡大させた形状をもつ. 衛星の外側は骨格に $1 \mathrm{~mm}$ のアル ミ板をはりつけている。この設計は，主として 25 年以内の 軌道落下の要求を満たすために, 面積質量比をできるだけ 大きくするために選択された. 2010 年 4 月の時点では単純 な $3 \mathrm{U}$ のキューブサットであったが, H2A 相乗りで 25 年以 内の軌道落下ルールが採択された後に, 急遽設計が変更さ れ, 同年 8 月に変更した. 打ち上げ時の荷重は, 主としてア ルミ製の骨格が受けることになっており, 試験と解析によ り徹底的に検証することとした。設計確認のための STM(Structure Thermal Model)を使った振動試験を, 2010 年 の 11 月下旬に行った.
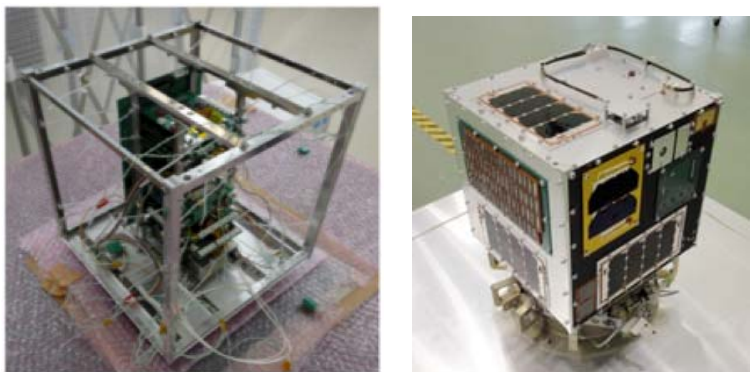

第 1 図 鳳龍式号の内部構造と外観

もう一つの例として, OBC(On-board-Computer)の設計例 を第 2 図に示す. $\mathrm{OBC}$ は同一種類の 2 個のマイコンを搭載 している. マイコンは、通称 H8 と呼ばれる自動車用の所謂 産業用マイコンを利用した. MAIN が衛星内のハウスキー ピング(HK)データと一部ミッションデータの取得と保存 及び, 各ミッション機器の ON/OFF を実行する. COM は地 上への送信データの作成, 受信機で受け取った地上からの コマンドの解釈と MAIN への受け渡しを行う. MAIN と COM は相互監視を行い，一方が一定時間内に返答信号を 送らなければ，正常な側が他方を強制的にリセットするよ うになっている.

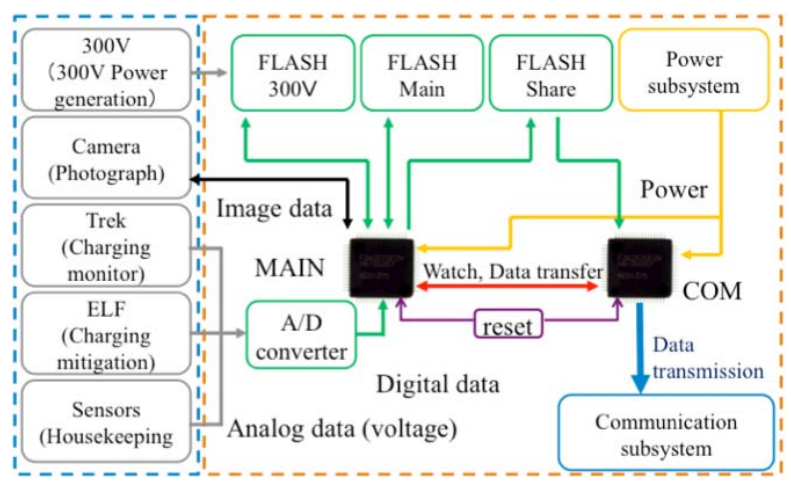

第2図 OBC サブシステムのブロック図

OBC を 2 個のマイコンで構成するのは,「鳳龍」から引 き継いだ設計であり, 過去に別の大学衛星で使われていた ということが主な理由であった。「鳳龍」の OBCについて は, 2010 年 3 月までに基本的なプログラミングを殆ど終え ていた，鳳龍式号向けにマイコンの種別を変更したりする ことは，スケジュール的にリスクが大きいとの判断から， ハードウェア的には, フラッシュメモリやインターフェー ス回路, $\mathrm{CPU}$ の動作電圧・クロックの変更等の小規模な変 更にとどめ, ソフトウェアをより充実させるという選択を 行った。 ハード的な変更を行わないため, 放射線試験によ り素子の選定を行うということはせず, (1)3 時間に一回定 期的にリセットを行う, (2) 2 個のマイコンによる相互監視, (3)3mm 厚のタングステンシートをマイコンとフラッシュ メモリの上に貼る, (4)OBCへの電力供給ラインに過電流防 止回路をつけ, $0.5 \mathrm{~A}$ 以上の電流が流れると供給電流を一旦 遮断する，といった対策をとるにとどめた. 


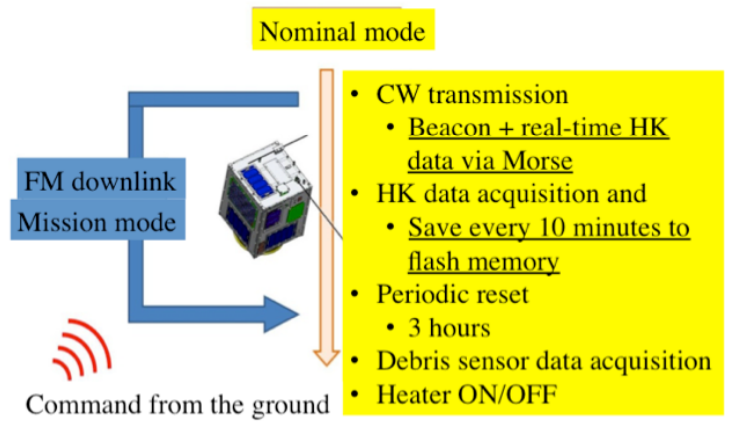

第 3 図 鳳龍武号の運用シーケンス

第 3 図に鳳龍武号の運用シーケンスを示す. 通常運用モ ードとして, 衛星は “JG6YBW HORYU”というコールサ インに引き続き, 15 文字からなるリアルタイムハウスキー ピング(RTHK)データを 1 文字あたり 0 F の 4bit 情報とし てモールス信号にて送出する。 このデータ送出は 20 秒程あ り，その後約 30 秒の間地上からのコマンドが来るかどうか を待ち受ける。コマンドが来なければ，再度コールサイン と RTHK データを送出する.この 1 分弱のシーケンスは, ミッション実行中またはパケットデータを送出中以外は常 に繰り返される.

通常運用モードでは, RTHK の送出以外に, より詳細な HKデータを 10 分間隔で MAIN マイコンが衛星内各部のセ ンサーから収集し，フラッシュメモリに保存している。こ のセンサデータは地上からダウンリンクを命じるコマンド を受けると, パケットデータに変換されて地上に送られる. 地上からのコマンドが送られてくると, COM がまずコマン ドを受領し, 受領した旨の返答信号を地上に返す.コマン ドは MAIN に渡され, センサデータダウンリンクのコマン ドの場合, MAIN は指定されたデータをフラッシュメモリ から取り出し, COM と共有しているフラッシュメモリに移 した上で, COM に保存先のアドレスを伝える. COM は教え られたアドレスからデータを抜き出して，地上に送り返す。

第 4 図に通信系のシステムブロック図を示す.コールサ インについては, PIC マイコンがデータを生成し CW(Continuous Wave)送信機にデータを引き渡す.コール サイン送出後はマルチプレクサを切り替えて OBC 基板に あるCOM が MAIN から受け取った RTHK データをモール ス信号に変換した上で $\mathrm{CW}$ 送信機に引き渡す. $\mathrm{CW}$ 送信機 は COM マイコンと PIC マイコンの二つが共有する形にな っているが, マルチプレクサの操作は PIC が握っており, PIC 側をより信頼した形になっている. PIC マイコンをコー ルサイン送出用に介在させた理由は, 万が一のサバイバル モードとして, OBC 基板に異常が発生してもコールサイン だけは出し続けて, 衛星を捕捉できるようにしたかったか らである. 打ち上げ後の不具合発生時も, 実際にこのよう に動作し, 衛星を失うことだけはなかった. PICマイコンを 選定した理由は, OBC 基板と異なるタイプのマイコンであ ること, 多くの大学のキューブサットで使用されていたこ
とにある.しかしながら, この設計でも, 第 4 図の FM 送信 機がパケットデータを送出中に COM マイコンが暴走を始 めると, PIC マイコンにはそれを止める手だてがない.

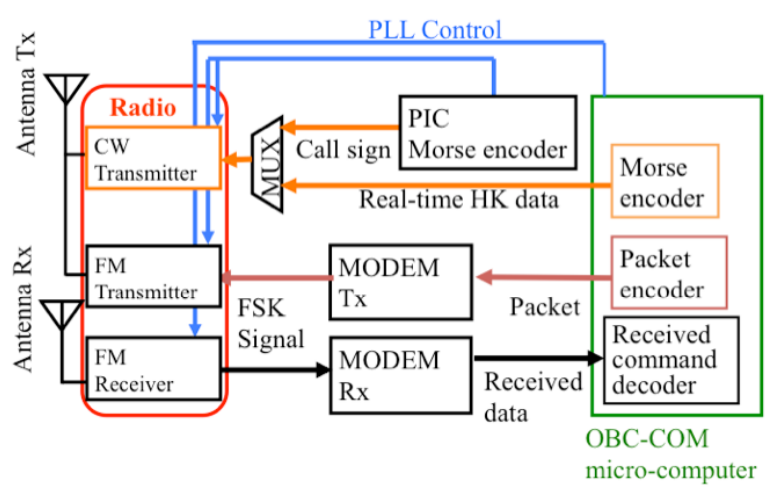

第 4 図 通信系サブシステムのプロック図

第 5 図に鳳龍式号の電源系のブロック図を示す. 電源系 はバッテリ電圧で維持されるようになっており, 非常にシ ンプルな構成となっている. しかしながら, ピギーバック の超小型衛星の宿命として, 打ち上げ中の誤作動防止のた めの分離スイッチが 3 直列で入っている. またミッション 終了後に太陽電池からの電力供給ラインを開放し, バッテ リを完全放電させるためのキルスイッチが，2 並列で搭載 されている. 電源系は, 万が一バッテリが枯渇した状態に 陥っても, 太陽電池からの電力供給がある限り充電はされ るように設計しており, 実際に地上試験で残量ゼロからフ ル充電されることを検証している. 第 6 図に地上試験のバ ッテリ電圧の変化を示す. 検証試験ではソーラーアレイシ ミュレータで軌道上の太陽電池出力変化を模擬し, 負荷側 では実際に CW 通信機を動かして通常運用モードと同じ電 力を消費させ続けた. 日照時の上昇と蝕時の下降を繰り返 しながら, ゼロ状態からフル充電状態にまで至っている.

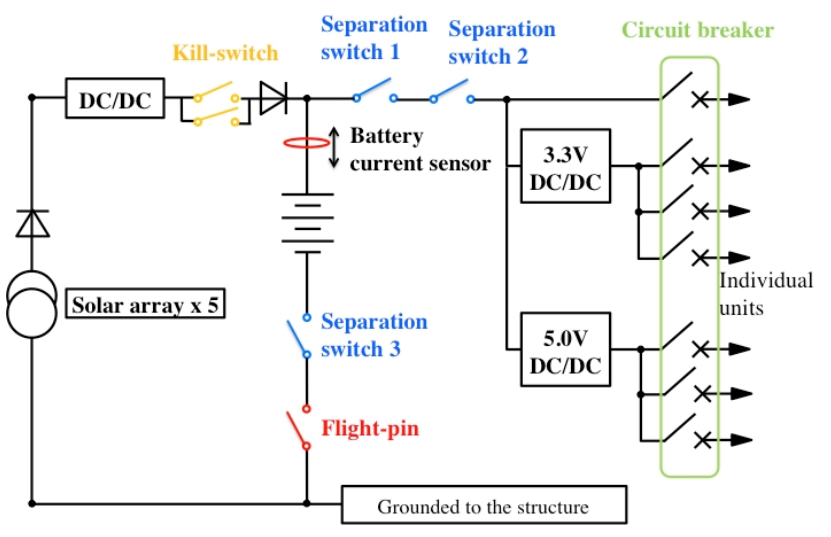

第 5 図＼cjkstart電源系サブシステムのブロック図 


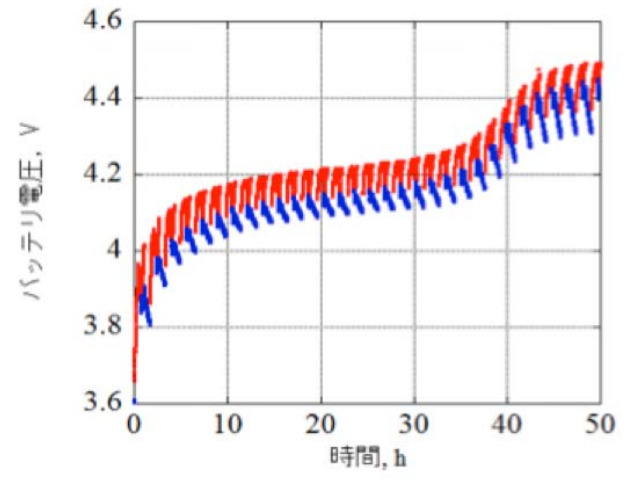

第 6 図 地上試験でバッテリ枯渇状態からの復活を模擬した時の バッテリ電圧の推移。（赤は充電時、青は放電時を表す）

\section{3. 鳳龍式号の試験・検証}

鳳龍武号の検証項目については, 衛星の概念設計ができ あがり, 各系の設計要求が出揃ったのと同時に検証要求も 列挙したものを作成した(2010 年 6 月初旬).また, BBM

(Breadboard Model), STM (Structure Thermal Model), EM(Engineering Model)を FM(Flight Model)製作前に作って 試験・検証を行うことを予め決定した. 途中, 打ち上げが遅 れることが判明したため, EMについては, 内部基板を入れ 替えた EM ver. 2 を作成し, FM 製作前の環境試験等を行っ た，検証においては，試験ができるものは，試験をするこ とを基本方針とした，九州工大の場合は，試験設備が学内 に揃っているために，そのような方針を取れるが，他の大 学や非宇宙の中小企業で同様の方針をとることは難しいか もしれない.

第 1 表に実施した試験を列挙する.これらは主としてシ ステム系の環境試験であるが, 電源系で常時実施していた 充放電サイクル試験や各種ミッション機器の機能試験等は 含まれていない. バスシステムの健全性を確認するために 行われた試験についての表と考えた方がよい. 尚, 衝撃試 験のうち, 29 番だけが衛星分離衝撃試験として火工品を使 用するために筑波宇宙センターで実施され，その他の衝撃 試験はフェアリング分離衝撃試験として, ハンマー式を用 いて九州工大で実施された. 29 番を除く全ての試験は九州 工大で実施された. 29 番の試験一回だけで, 九工大側だけ でも50 万円を超す費用（主として衛星本体の輸送費）と 10 日近い日数を要している. 衛星の移動に伴う時間と費用 は無視できないものである

第 2 表に試験にかかった延べ日数を人・日で示す. 第 1 表にある試験に加え, ミッション機器の機能試験や地上局 リハーサル等も含めている. 第 2 表は非常に大きな数字々 なっているが, 衛星開発や試験を初めて行なう学生ばかり であるため, 試験を効率的に実施できずに, 日数が多くか かっている. そのため, 第 2 表にある数字を従来の衛星と そのまま比較するべきではない. 振動と衝撃に多くの時間
が割かれているが，これは他の相乗り衛星と同様の傾向で ある ${ }^{4)}$. 特徵としては, 熱真空試験とアンテナパターン試 験に非常に多くの時間を割いている．また，ミッションペ イロード試験に多くの時間を使っているのは, ミッション が多岐にわたるからである. 各ミッション担当が実施した 環境試験前後の機能試験を積み重ねるとこのような数字に なる.

第 1 表 鳳龍式号で実施した試験. 数字は実施順

\begin{tabular}{lccccc}
\hline 試験項目 & 回数 & STM & EM & EM ver. 2 & FM \\
\hline アンテナパターン & 1 & 1 & & & \\
\hline 振動 & 7 & 2,3 & 8,11 & 16,18 & 27 \\
\hline 電気インターフェース & 3 & & 4 & 13 & 20 \\
\hline 通信 & 3 & & 5 & 17 & 23 \\
\hline 熱平衡 & 1 & & 6 & & \\
\hline 衝撃 & 6 & 7 & 10 & 15,19 & 28,29 \\
\hline 熱真空 & 4 & & 9 & 14 & 22,24 \\
\hline 機能 & 3 & & 12 & & 26 \\
\hline ベーキング & 1 & & & & 30 \\
\hline End-to-End & 1 & & & 31 \\
\hline フライト品検査 & 2 & & & 21,25 \\
\hline
\end{tabular}

第 2 表 鳳龍弐号で実施した試験にかかった延べ日数. 数字は人・日

\begin{tabular}{lrrrrr}
\hline 試験項目 & 計 & STM & EM & $\begin{array}{l}\text { EM } \\
\text { ver. 2 }\end{array}$ & FM \\
\hline アンテナパターン & 90 & 90 & & & \\
\hline 振動 & 294 & 110 & 90 & 63 & 31 \\
\hline 電気インターフェース & 45 & & 5 & 26 & 14 \\
\hline 通信 & 124 & 89 & 23 & 12 \\
\hline 熱平衡 & 120 & & 120 & & \\
\hline 衝撃 & 185 & 9 & 60 & 50 & 66 \\
\hline 熱真空 & 492 & & 74 & 169 & 249 \\
\hline 機能 & 31 & & 8 & & 23 \\
\hline ベーキング & 59 & & & & 59 \\
\hline End-to-End & 81 & & & & 81 \\
\hline フライト品検査 & 51 & & & & 51 \\
\hline ミッションペイロード & 577 & & & & \\
\hline 地上局運用リハーサル & 62 & & & & \\
\hline 合計 & 2289 & 209 & 446 & 331 & 586 \\
\hline
\end{tabular}

アンテナパターン試験は, アンテナとケーブルの間の結 合を学生が行ったが，技術の未熟さから準備に多大な時間 を要した．また供試体に STM を使ったがその組立に時間 を要したり, システム試験の最初であったことから, 試験 の進め方全般にわたって手際が悪かったことにもよる. 熱 真空試験にかかった時間が多いのは, 様々な不具合が露呈 し，そのトラブルシューティングに多大な時間を要したこ とによる. 
超小型衛星「鳳龍武号」の試験・検証と軌道上不具合原因究明（趙孟佑・増井博一・九工大衛星開発プロジェクト）

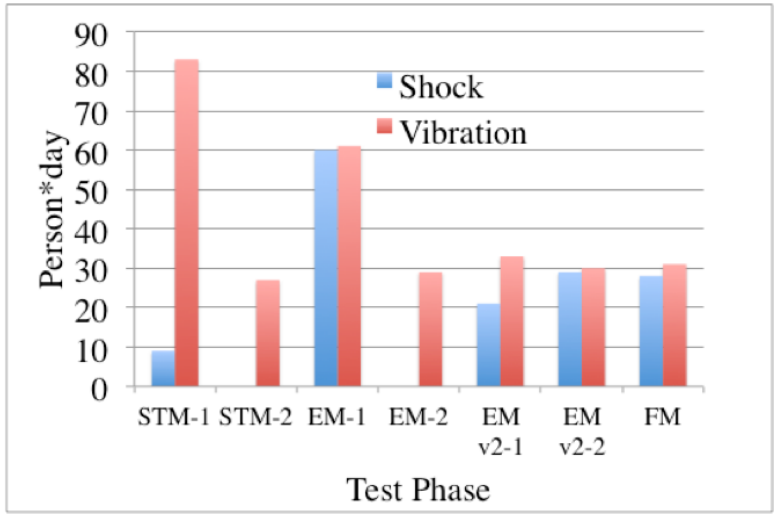

第 7 図衝撃試験と振動試験にかかった日数

第 7 図に振動試験と衝撃試験に要した延べ日数を示す. 回を重ねる毎に, かかる日数がほぼ一定に落ち着いている. また, EMの最初の試験で日数が急激に増加しているが, こ れは STM では含まれなかった内部電子基板が試験対象に 含まれたからで, 分離スイッチのチャタリング検知回路の 誤動作への対処や, 各基板の前後での動作確認等に時間を 要したためである. 学生衛星の場合, 初めての試験では手 際の悪さが目立ち, 試験にかかる日数の見積もりが甘いこ とが多い.しかし，一旦経験を積んでしまえば，次からは 着実に作業をこなすことができる. 試験チームが経験者を 含むか含まないかで, スケジュールが大きく左右されるの で, 注意が必要である。

試験中に露見した主な不具合について述べる. 電気的 インターフェース試験では, 基板間のインピーダンス不整 合, 各機器の ON に伴う突入電流, マイコンと各ミッショ ン機器間の通信の不具合等の問題が明らかになり, 設計変 更につながった，振動試験では，多くの部品が脱落し，基 板への素子の実装方法に改良を加えた. 衝撃試験では, 通 信機部分の JST コネクタに緩みが露見し, フライト品では コネクタ部分を接着剂で固定することとした，また，展開 アンテナが飛び出すという不具合も発生し, 展開アンテナ の抑え部分の設計変更につながった.

熱真空試験では, FM パケットデータが地上局でデコー ド不可となる不具合が露見し, 通信基板の回路に使われて いる抵抗素子の值を変更しなければいけないことがわかっ た. また, FMの熱真空試験の際に, OBCに外部の PCからつ ないだケーブルに外部からノイズが侵入し, 通信機に不具

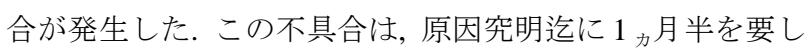
た. 衛星自体の不具合ではないものの, 試験を円滑に実施 するにはノイズ対策が極めて重要であることを示している. FM 熱真空試験の不具合は, 衛星周囲の温度によって発現 したものではなく, 衛星の全系を一旦組み立てた機能試験 でも起きうるものである. 熱真空試験はやればよいのでは なく, 真空容器に入れて衛星へのアクセスが極めて不便に なる前に, 全系組み合わせた状態での大気中での機能試験 を十全に行うべきである. 超小型衛星の場合, スケジュー ルに押されて, 熱真空試験をやることを優先させて, その 前の機能試験がおろそかになる場合が多々ある. 大気中の
機能試験を十全にやっておくことが, 結局は時間の節約に なる.

FM の機能試験は, 主として所謂テーブルサットを意 味している. FM 品と同じ基板及び通信機だけを机上に並 ベ, フライトソフトウェアの連続動作試験を行ってバグ取 りを行ったが, 多数のバグが露見している.

End-to-End 試験は, FM のハードウェアの試験が全て 完了し，筑波宇宙センターへの納入迄の間に集中的に実施 した，試験では衛星をクレーンで吊って, 電気的に完全に 孤立させ, 衛星内のバッテリで駆動させた上で電波を使っ て地上局との間の通信を行った。この試験は, FM の特にソ フトウェアに関する最終チェックであると共に, 地上運用 人員のトレーニングも兼礼ている. 通常運用モードを最大 で 2 時間連続させると共に, 全てのアップリンクコマンド を試して衛星の応答を調べた。 また, 定期リセットの確認 のため, 外部電源駆動で最大 5 時間程の連続駆動試験も行 なっている. 試験中に, RTHK データでモニタしているキ ルスイッチの一つが ON（即ち開放）を示す事象が発見さ れた. 実際にスイッチが ON になっているわけではなく, COM がハングアップするなどして, MAIN が COM のリセ ットをする際のシーケンスにかかわるプログラムにバグが あることが原因であることが判明した. 3 時間に一度の定 期リセットで問題が解決することを確認した。この事象は, 試験の最終段階, 即ち納入の直前で判明したため, プログ ラム変更に伴う別のバグの混入を防ぐため, プログラムに は修正を加えずに，そのまま納入した。

\section{4. 軌道上不具合}

2012年 5 月 18 日に打ち上げられて以来, 鳳龍弐号の状態は 極めて良好であり, RTHK や 10 分毎の詳細センサデータに も異常は見られなかった. 衛星のバス系は正常と判断し, そろそろミッションペイロードを動作させようとしていた 矢先の 2012 年 6 月 5 日に不具合が発生した. 確認された 事象は以下の通りである.

・RTHK データの内容が更新されない.

・RTHK データに含まれるキルスイッチのステータスの一 つが ONを示す

・詳細センサデータ等をダウンリンクさせようと地上か らコマンドを送っても，コマンドの受信を確認する信号が 返ってくるのみで, データが送られてこない.

・地上から強制リセットコマンドを送っても, 上記の事象 が変化しない.

これらの事象から, OBC の MAIN マイコンまたはマイコン にリセットをかける素子(スイッチ， 3 ステートバッファ 素子)に問題があると考え, 不具合究明作業を行った. 不具 合発生箇所は, 更新が止まり固定されてしまった RTHK デ 一タの值 (バッテリ電流と通信機温度) から, 蝕明け 10 20 分後であると推定した. 推定された箇所はブラジル南東沖 の南大西洋異常帯に合致していた. FTA 解析を経て残され た推定原因は以下の通りであった。

1. 熱サイクルによる素子ハンダ部で不良が発生 
2. 内部帯電によって OBC 基板上で放電が発生

3. 外部から異物が混入し, 基板上で短絡が発生

4. リセット素子が放射線の影響をうけて故障

5. マイコンがシングルイベント効果(SEE)により暴走

推定原因の 1 については, 予備の基板を窒素ガス雾囲気 中で熱サイクル試験にかけた. 不具合発生までにとれてい たセンサデータから, 各基板の温度は最大で $-5 \sim+25^{\circ} \mathrm{C}$, 殆 どの場合が $0 \sim+20^{\circ} \mathrm{C}$ 収まっていた. 不具合発生までの倍 の 600 サイクルを, 1 サイクル 15 分の急速度で, しかも温 度範囲を-10 +40 $\mathrm{C}$ に拡大してかけたが, 基板には何の不 具合も見当たらず，電気的機能にも何の問題もなかった. この基板は, インターネットで実装を業者に依頼するもの で，ハンダ付けの手法は通常の民生品向けと同じものであ る. そのような製作方法であっても, 温度サイクルには充 分耐えることが判った.

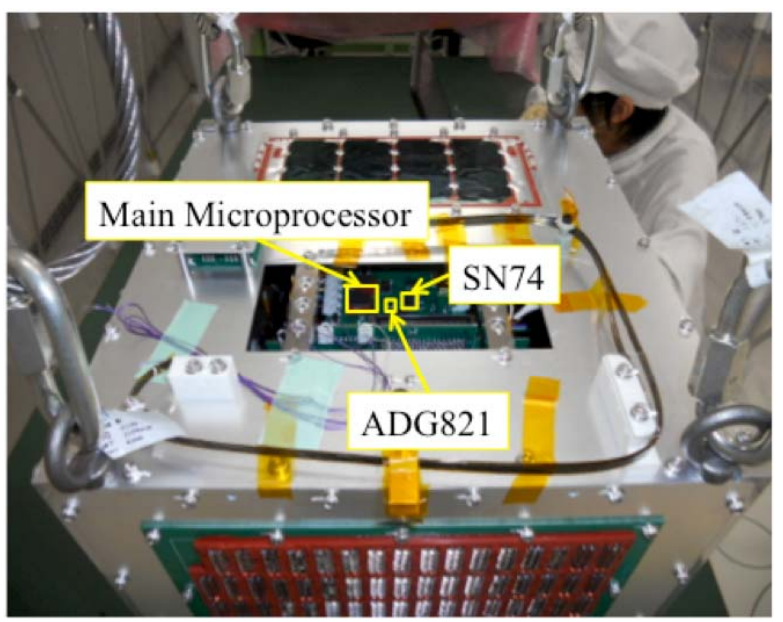

第 8 図 OBC 基板の帯電緩和過程

$\mathrm{OBC}$ 基板は, 第 8 図に示すように衛星の外板 ( $1 \mathrm{~mm}$ 厚 のアルミ板）のすぐ内側にある. 地上での作業中はアクセ スポートが上に向いているため, 異物混入の可能性は捨て きれない.アクセスポートは横向きにす心゙きという大きな 教訓を得た. $1 \mathrm{~mm}$ 厚のアルミ板は $500 \mathrm{keV}$ 以上のエネルギ 一の電子は貫通できる. 素子を含む基板の厚みが数 $\mathrm{mm}$ 厚 として, $500 \mathrm{keV}$ から $2 \mathrm{MeV}$ 程度までの電子が $\mathrm{OBC}$ 基板を 帯電させることになる. 基板上にはむろん多くの接地が存 在するので, 帯電電荷は抜けていくことになるが, 電荷の 抜けが遅ければ，帯電は時間と共に進行していくことにな る.

実際にどれくらいの時定数で抜けるかを調べるために, 予備基板を真空容器にいれ, 数 $\mathrm{keV}$ の電子ビームを照射後 に，どれくらいの速度で電荷が抜けていくかを測定した. 第 9 図に結果を示すが, 数時間経っても電荷は抜け切って いないことがわかる．帯電電位をあげたところ，-3. $5 \mathrm{kV}$ 程 度で放電を確認した。鳳龍武号と同様の軌道を飛行してい る GOSAT の LPT(Low Particle Telescope)が計測している $500 \mathrm{keV}$ から 1. $6 \mathrm{MeV}$ の電子フラックスのデータを解析し
たところ，打ち上げから 6 月 5 日迄の間， OBC 基板は $1 \times 10^{-10} \mathrm{~A} / \mathrm{m}^{2}$ 程度の電子電流を浴びていたことが判った. 基 板上の絶縁体の静電容量にもよるが, 地上試験結果から 4. $4 \times 10^{-7} \mathrm{~F} / \mathrm{m}^{2}$ と仮定すると, $3.5 \mathrm{kV}$ まで帯電させるには, 電流 量が 1 桁以上足りないと思われる. 今回は内部帯電を推定 原因から外すことができるが，超小型衛星は，薄板一枚で 外界から隔てられている場合が多く, 超小型衛星搭載の電 子基板の帯電については, 今後検討していく必要があると 思われる.

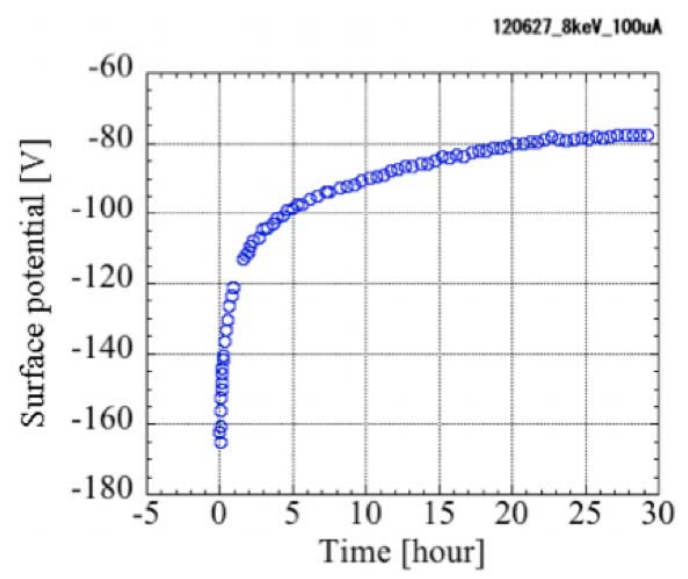

第 9 図 OBC 基板の帯電緩和過程

4, 5 の推定原因を確かめるために, 8 月に SEE 試験を実施 す心゙く準備を進めていたが，その途中の 6 月 30 日に, CW 信号のうちビーコンは送られてくるものの, RTHK データ が送られてこない状態に陥った. 地上からのコマンドへの 返答信号も送られてこなくなった. おそらくは, COM マイ コンが不調となり, PIC マイコンのみで動作している状態 になった. 非常に危機的な状態となったが，その後 7 月 3 日の早朝のデータ受信時に CW 信号が正常に戻っているこ とが確認され, RTHK も更新されていることを確認した. 急ぎ，詳細センサデータをダウンロードして衛星の状態を 確認したところ, バッテリがほぼ枯渴状態にあることが判 った. バッテリはその後, 正常な状態まで充電され, 現在 （11月 22 日）に至るまで衛星は正常に動作を続けている. 以上のことから, 今回の不具合は不可逆的な故障が起きた ものではないことがわかる，放射線の影響であったとして も，トータルドーズ(TID)は除外できる.

SEE 試験は京都大学原子炉実験所にて, カリフォニウム 照射試験装置を用いて行った. MAIN・COM の二つのマイ コンとリセット関連素子のプラスチックパッケージを取り 除いた状態にした上で OBC 基板に実装し, 通信・電源の各 予備基板及び通信機と共に照射試験装置に入れた。マイコ ンは, 鳳龍式号搭載品(HD64F36057FZJV) とは全く同じ型 番のマイコンが生産中止になっていたため, 型番の末尾に 文字が 1 文字追加されただけの同等品（HD64F36057FZV, 
超小型衛星「鳳龍武号」の試験・検証と軌道上不具合原因究明（趙孟佑・増井博一・九工大衛星開発プロジェクト）

搭載品に比べて, 温度範囲が異なる. 歩留まり率が向上し ている）を用いた。 ${ }^{252} \mathrm{Cf}$ の核分裂に伴い, 僅かな確率(3\%) ながら ${ }^{252} \mathrm{Cf}$ からは中性子の他に 102.5 と $78.7 \mathrm{MeV}$ を中心 とするそれぞれ 106. 2 と 142. 2 AMU の重イオンが放出さ れる. シリコンに対する平均の LET は $43.0 \mathrm{MeVcm}^{2} / \mathrm{mg}$ で ある. 試験の目的は SEE, 特にラッチアップが発生するか, 発生したとして外部からリセットがかけられるかを調べる ことを最優先とした.リセット関連素子では SEE は確認さ れなかったが, マイコンではSEE を容易に確認することが できた. 第 10 図に試験結果を示す. 線源を $2 \mathrm{~cm}$ 上においた まま, MAINを ONすると, 1 分以内に SEE が発生し, 消費 電流（外部電源からの電流供給ラインを計測）が $0.1 \mathrm{~A}$ ス テップ状に増加し, マイコンは暴走を始めた. また, MAIN を暴走させたまま COM の上に線源を移動させると, COM 側でも暴走が始まり, 電流が更に 0 . 1A 増加した。 なお, マイコンが暴走を始めると, 外部 PC からリセットコマン ドを送っても, リセットがかからないことも, この図には 示したのとは別の照射時に確認している. マイコンを元の 状態に戻すには, 外部電源を一旦才フするしかなかった。

試験では, 実際に鳳龍武号の電源基板を介して OBCに 電力を供給していたが, 第 10 図 のようなシングルイベン トが発生しても, 電源基板の過電流防止回路は発動しなか った.このことからも, 過電流防止回路の設定值以下の電 流が流れ続けたと思われる。

尚, GOSAT の LPT データによると $5 / 18$ から 6/5 迄の間の 53 130 MeV のエネルギーの陽子の立体角あたりの平均フ ラックスは20 30 $\mathrm{cm}^{-2} \operatorname{str}^{-1} \mathrm{~s}^{-1}$ であった. 試験に使用したカリ フォニウム $\left({ }^{252} \mathrm{Cf}\right)$ の強度は $22 \mathrm{kBq}$ であり, $2 \mathrm{~cm}$ 上から照射 した時の重イオンのフラックスは $23 \mathrm{~cm}^{-2} \mathrm{~s}^{-1}$ であった. 同等 のフラックスであっても, 南大西洋異常帯で支配的な陽子 に比ベて, 重イオンの方が遥かに高い確率でシングルイベ ントを起こせることがわかる. 残念ながら, ${ }^{252} \mathrm{Cf}$ の試験結 果から陽子によるシングルイベント確率を算出することは できない.

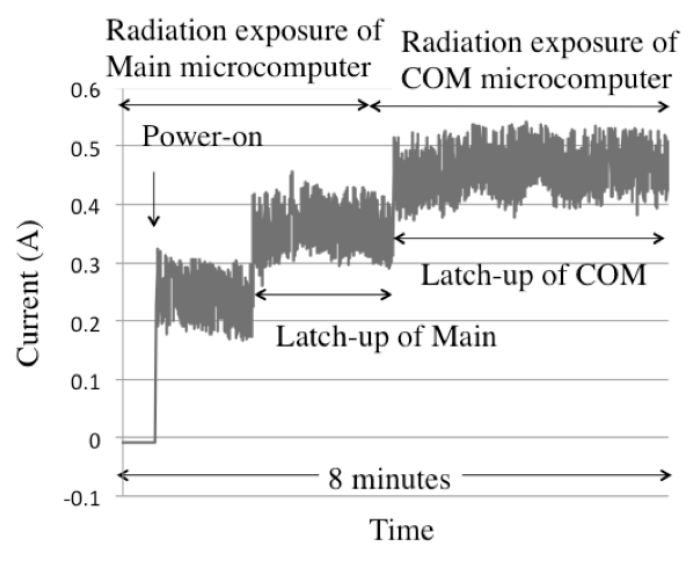

第 10 図 カリフォニウム照射中の外部電源の供給電流

このSEE 試験の結果から, 鳳龍武号の不具合は以下によ
ると思われる. マイコンが放射線を浴びてラッチアップを 起こし, リセットも受け付けない状態となった(6/5). 2 個 目のマイコンがラッチアップを起こし（6/30），消費電流 が増加しすぎてバッテリ充電が追いつかず, バッテリが枯

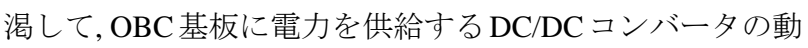
作電圧の下限を下回って, $\mathrm{OBC}$ 基板への電力供給が止まっ て,マイコンがリセットされた（7/3）

7 月 3 日に復帰後, しばらくは通常運用のみでバッテリ の再充電を行なった. その時のバッテリ電圧の変化を第 11 図に示す. 第 6 図に示したのとほぼ同じ時間でバッテリが 枯渴状態から復帰したことがわかる.

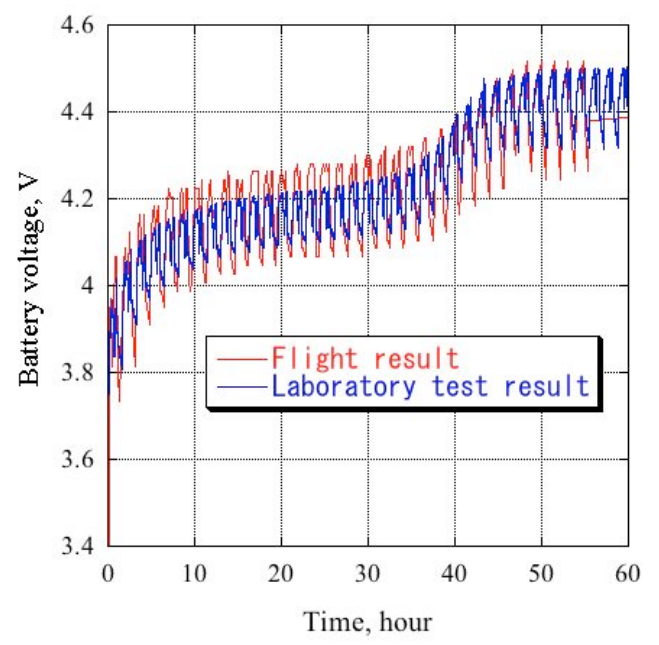

第 11 図 復帰後のバッテリ電圧の推移

SEE によって軌道上不具合を再現することはできたもの の, 不具合究明作業では, 未だ二つの項目が閉じられずに いる. 一点目は, 不具合発生箇所である. 当初, 固定された RTHK データから発生箇所が南大西洋異常帯であると推定 したが, 衛星の復活後にフラッシュメモリに残された詳細 データを解析したところ, 正常なデータが書き込まれた最 後の地点はブラジル南東沖ではなく, それより 30 分程前 の西太平洋の赤道付近（ニューギニア上空）であった.二 つのデータが全く異なった地点を示しているが, 限られた 情報からは，これ以上発生箇所を突き詰めることはできな かった. 二点目は, 不具合が SEE により起きたとすると, マイコンはほぼ 3 週間に一度の間隔でSEEを起こしている が, 復活後 4 ケ月以上が経過しても, 衛星は順調に飛行し ている. 本来であれば, 次の SEE が起きてもおかしくなく, この点についても不明である。

\section{5. まとめと今後の課題}

超小型衛星「鳳龍式号」の試験・検証と軌道上不具合原 因究明作業について述べた. 打ち上げ前の試験・検証には 膨大な時間を費やした。学生衛星であるが故の, 組み立 て・製作技術の未熟さや試験作業の不手際が時間を増大さ せる要因ではあるが，これらは経験を積めば確実に減少す 
る. 民生品を用いた大学衛星であっても, クリティカルな コンポーネントの製造を民生技術分野で良いので熟練者に 委託し, 振動・熱サイクル試験等でワークマンシップのレ ベルを確認できれば, 衛星は充分に動作する.

新規開発の衛星であったので，EM 段階での試験は設計 の不具合を洗いだすのに有効であった. End-to-End 試験は, 運用リハーサルとしても, ソフトウェアのバグだしのため にも非常に有効である. 熱真空試験でも不具合が見つかっ たが，それらは大気中の機能試験でも見つかった可能性が あり, 熱真空試験を実施する際には, その前に全系組み立 てた状態での機能試験を十全に行うことが, 結局は時間を 節約することになる.

SEE 試験を行う超小型衛星はそれほど多くない. 理由の 一つには試験設備が限られており, 基板設計を行う前に SEEやTID 試験で素子をスクリーニングするのに充分な時 間を割いていられない事情もある.しかしながら, 少なく とも, バス基板レベルでの SEE 試験を行って, SEE 発生時 のバス系の挙動を把握し, 耐放射線設計の有効性を検証す べきである. 鳳龍式号では SEE 対策として OBC 基板への 電力供給ラインに過電流防止回路を挿入し, 0. 5 A を動作 しきい值においた.しかし, 0.5 A というしきい值の有効性 の検証が欠けており, SEE 発生時の消費電流増加はそれを 下回っていた. また, リセットで SEE から回復すると思っ ていたが, SEE 時にリセットが有効かどうかも未検証であ った。

不具合が発生したとしても, 様々なサバイバルモードを 用意し，それを実際に検証しておくことが大事である. 鳳 龍武号は幸いにして, バッテリが一旦枯渇したことにより 復旧したが, バッテリが枯渇状態から復旧できることは設 計要求に挙げられており, 試験で検証済みであった. また, PIC マイコンによるビーコンの確保も設計通り動作した. 但し, ビーコンだけでなく, 最低限の HK データも確保で きていれば, 衛星の内部状態を探るのに大きく役立ったと 思われる. サバイバルモードは衛星の大きさによらず必要 であるが, 圥長系の少ない超小型衛星にとって, その重要 度は非常に高い。

今回の不具合究明作業を通じて, 内部基板の帯電など, 新たな知見を得ることができた. また衛星の試験作業にお いても, ノイズ対策や衝撃試験において, 様々な教訓やノ ウハウを得ることができた. 今後はこれらの知見・教訓・ ノウハウを他の超小型衛星開発者と共有し, 超小型衛星の 信頼度の向上に努めたい.

鳳龍武号の設計・開発・試験・運用におきまして, 多く の方々からいただいたご支援・ご協力に感謝いたします. 鳳龍武号の不具合原因究明に際してご協力いただきました, 京都大学の高宮幸一准教授, JAXA の松本晴久氏, Japan Space Systems の三浦末志氏, 東京大学の鶴田佳宏氏に感謝 いたします. 本研究の一部は, 総合科学技術会議により制 度設計された最先端研究開発支援プログラムにより, 日本 学術振興会を通して助成されたものです.
1) J. Bouwmeester, and J. Guo, , "Survey of worldwide pico- and nanosatellite missions, distributions and subsystem technology", Acta Astronautica, 67, 2010, pp. 854-862.

2) Gregory F. Dubos, Jean-Francois Castet, Joseph H. Saleh, "Statistical reliability analysis of satellites by mass category: Does spacecraftsizematter?", Acta Astronautica, 67, 2010, pp. 584-595.

3) http://kitsat. ele. kyutech. ac. jp/index. html

4) 趙孟佑, 増井博一, 入江大樹, 西尾正則: 超小型衛星の検証コスト に関する試算, 2010 年度宇宙科学技術連合講演会, 1 C04, 2010.

5) J. H. Stephen, T. K. Sanderson, D. Mapper and J. Farren, R. Harboe-Sorenseon, L. Adams, "A Comparison of Heavy Ion Sources Used in Cosmic Ray Simulation Studies of VLSI Circuits", IEEE Trans. Nucl. Sci. , NS-31, p.1069, 1984 